\title{
Mistrust in Dysfunction, Culture in/Sensitivity in Era of Pandemics: How Ibibio People of South Eastern Nigeria Responded to 1918-1921 Influenza Vis a Vis COVID-19 Pandemics
}

\author{
Michael Onyedika Michaels ${ }^{1}$, Felicia Ihuoma Michaels ${ }^{2,3}$ \\ ${ }^{1}$ Sociology of Education, Ontario Institute for Studies in Education, OISE University of Toronto, Toronto, Canada \\ ${ }^{2}$ History, Women and Gender Studies, University of Lagos, Nigeria, Africa \\ ${ }^{3}$ History and Women Studies and Social Work, University of Toronto, Toronto, Canada \\ Email: mmichaels@sk.johnhoward.ca, feliciamichaels2000.com@yahoo.com
}

How to cite this paper: Michaels, M. O., \& Michaels, F. I. (2022). Mistrust in Dysfunction, Culture in/Sensitivity in Era of Pandemics: How Ibibio People of South Eastern Nigeria Responded to 1918-1921 Influenza Vis a Vis COVID-19 Pandemics. Sociology Mind, 12, 1-19.

https://doi.org/10.4236/sm.2022.121001

Received: November 21, 2021

Accepted: December 21, 2021

Published: December 24, 2021

Copyright $\odot 2022$ by author(s) and Scientific Research Publishing Inc. This work is licensed under the Creative Commons Attribution International License (CC BY 4.0).

http://creativecommons.org/licenses/by/4.0/

(c) (i) Open Access

\begin{abstract}
In an exhibition of social responsibility against COVID-19 outbreak, almost all governments of African nations have taken proactive measures to close down potential sources of the virus transmission to the public. In this paper we engaged sequential text interpretation of historical and current health documents, professional publications and media reportage on the post WW1 influenza and the ongoing COVID-19 pandemics in order to fully explore the tensions and issues arising from the responses of Indigenous Ibibio people of South Eastern Nigeria to the pandemics' interventions. We employed anti-colonial theory and the philosophical trajectory of African traditional ecological knowledge, TEK to investigate the two devastating global pandemics. We observed that the Ibibio people's responses to intervention efforts of the ruling authorities and NGOs in the two pandemics were shaped by suspicion, and as the world is urgently turning into a densely populated global village, trust has become an essential commodity with respect to ways professional multinational corporations and agencies deal with the Indigenous peoples around the world. Non-toxic, unbiased, and accurate information from media reportage is sine qua none in fostering trust and restoring the confidence of Indigenous communities in Western science, a condition marred by misinformation and experiences of racism and stereotype. We argued that a multi-world approach to understanding and finding solutions to global socio-cultural, and health problems will provide sustained benefit to the multicultural society the world has become. We conclude by advising that the continents of the world share a collection of diverse Indigenous peoples' epis-
\end{abstract}


temic saliencies (lived experiences). The unique ecological approach each of the Indigenous communities has lived with over the centuries constitutes their identity with the ecological environment. To gain the trust and acquiescence of these communities with respect to disaster interventions, these beliefs and practices, including in matters of health emergency, should be, evaluated, and incorporated into programs intended for the Native peoples.

\section{Keywords}

Influenza, Epistemic, Ecological, Intervention, COVID-19, Response, Colonial

\section{Introduction}

In this paper we engaged African traditional ecological knowledge TEK to focus on the responses of the Indigenous Ibibio people of South Eastern Nigeria to the two devastating global pandemics: 1918-1921 Influenza and the current COVID-19 Pandemics. We aim to accentuate the Indigenous African peoples' responses to the post-WW1 influenza and the current COVID-19 pandemics with a view to eliciting better understanding of the ecological, political and socio-cultural dynamics within these time frames that have influenced the peoples' responses towards the pandemics. The paper finds pertinence in addressing the negative perceptions of Indigenous Africans' dispositions towards foreign aids and healthcare assistance. With particular reference to the ongoing measures to find vaccines and safeguard against COVID-19 pandemic, some global healthcare institutions, scholars, international non-governmental organizations and individual stakeholders have misread, misinterpreted and therefore mischaracterized African Indigenous peoples' deportment as unresponsive, needlessly wary, and ignorantly suspicious to the current anti-COVID-19 projects. In fact, Melinda Gates, co-chair of the Bill and Melinda Gates Foundation, and wife of American billionaire-philanthropist, Bill Gates vented her frustration on CNN interview with respect to the emergency preparedness of Africans against the impending onslaught of COVID-19 pandemic when she warned that if the world would not act fast enough "there will be dead bodies all over the streets of Africa" (Nathaniel, 2020: p. 2). Such a show of concern might be timely and plausible but this paper will do more by throwing some light at the possible lines of discontent. An analysis of the Indigenous peoples' response to the global onslaughts of the two most dreaded health disasters in the history of human civilization would equip readers to aptly draw insightful and empathetic conclusions, and possibly make accurate predictions and apposite preparation for future projects intended for Indigenous communities. The paper will engage anti-colonial theory while drawing largely from Indigenous philosophical models in attempting to respond to the following questions: how have the social and mainstream media outputs influenced the response of the Indigenous Ibibio people of South Eastern Nige- 
ria to the post-WW1 influenza and current COVID-19 pandemics? Did the pre-colonial Indigenous Africans' Ways of Knowing accommodate and encompass the peoples' response to environmental phenomena, including their epidemiological and pharmacological needs? What global social and economic factors inform Indigenous Nigerians' response to the pandemic interventions?

\subsection{Review of Literature: Traditional Ecological Knowledge and Indigenous Education}

Situating traditional ecological knowledge in Indigenous education evokes a rush of intuitive ambivalence: a sense of historical nostalgia that unsettles existing belief system bolstered by colonial logics, which tends to deny Indigenous peoples' philosophies and epistemological predisposition. It also invokes admiration of the seductive neocolonial tropes embedded in the hegemonic assumption of knowledge in which Western science subsumes all other knowledge-bases to the margin. For according to Willinsky (1998) the imperialists' quest was not only described as an expression of the resolve to know, which in itself was nurtured by the unparalleled hunger to amass power that aims albeit, subtly at the creation of distinctiveness and otherness, but also the weird, "stand-aloof companion" from the colonialists' hegemonic drive for political and economic expansion (Willinsky, 1998, p. 51). Western science assumes a reified status, and becomes validated as the criteria for all forms of human civilization and advancement. It therefore doubles as a tool for demonization and domination of the colonized peoples' pre-existing knowledge-base, and an inalienable scepter of imperialists' authority. Willinsky argued that the imperialists' "will" to know cannot be divorced from their unconscionable and uncontainable crave for power, an obsession achievable only by

Cartesian mind-body dualism. This split separated the decidedly European mind from nature's body: "To know nature, one must make it alien, perceive it as fundamentally other" ... One can imagine how the degree of detachment afforded by distance might lighten concerns about imperialism's subjugation of peoples and territories. They were objects of study, the knowledge of which benefited humankind (p. 51).

The whole process of the imperialist movement, which often masks as civilization through dissemination of knowledge, is hence, clearly a quest for power and domination for economic and political gains. To explore the responses of the Indigenous Ibibiopeoples of South Eastern Nigeria to the two devastating global pandemics: 1918-1921 Influenza and the current COVID-19 pandemics through the lenses of traditional ecological knowledge will most likely generate a pellucid vantage from which to dispassionately appraise the rationale of such responses. Indigenous Africans' traditional ecological knowledge comprised the philosophical, epistemological, and experiential understanding the peoples share with their physical environment and cosmos over centuries, which is balanced on African peoples' Indigenous education and ways of knowing. African Indi- 
genous education relates to all forms of environmentally relevant knowledge production, validation, and dissemination. The Ibibio people's, and by extension African peoples' Indigenous education involves co-construction of knowledge (Nwalutu, 2015). Relevant to this paper is the understanding that Indigenous peoples' TEK provides them the environmentally relevant recipe for resolving and managing their immediate ecological problems (including medical, pharmacological, spiritual, cultural, and socio-political emergencies). Implication of this expose for the thematic-core of the paper remains that of incrimination of the colonialists for their justification of the hegemonic clout wielded over African nations through demonization, and denial of the continent's traditional ecological knowledge-base (Lebakeng, 2010). No doubt, pre-contact African pharmacological and medical systems had advanced and was sustaining the inhabitants of the continent for centuries before the Arabic, European and recently, Indo-China colonial contacts; and as it happened to other colonized Indigenous peoples and cultures around the world, the colonizers benefitted immeasurably from the Indigenous peoples' vast ecological knowledge-base before imposing their authority on the peoples and their heritages (Isichei, 1983; Belanger, 2018; Smith, 1999). The goal of engaging TEK in this work is to inspire authorities and institutions of learning to challenge the predominant colonial views, constructs, and theorizations that hitherto have denigrated Indigenous African Ways of Knowing, and therefore have continued to cripple meaningful and environmentally relevant socio-economic development in the continent.

\subsection{Pandemics in Empires' Rhetoric: Of the World and the Politics of Virus}

Since the invention of knowledge in the field of micro-organism and microbiology, humanity has seen a spike in outbreak and spread of fungal, bacterial and viral related diseases. The world is yet witnessing the intensifying cases of viral politics beyond domestic borders. No doubt, even if empirical evidence and logic do not support the idea of some of the globally recognized epidemics and pandemics emanating from human activities to develop biological weapon, several media information have at least incriminated scientists who by dint of error or willful intention exposed or attempted to transport deadly strains of micro-organisms across transnational borders. We would examine these incidents with the view of bringing the contents of some of the evaluated documents to critical scrutiny, and exposing the underlying realities of the events that generate distrust of Indigenous peoples against Western science. Media information on the $21^{\text {st }}$ Century Wire reads:

Today, biologists who worked in the former Soviet Union-like those who responded to a case of the plague across the border in Kyrgyzstan this week-are likely to brush Alibek's fears aside. But they'll also tell you that the fall of the Soviet Union devastated their profession, leaving some once prominent scientists in places like Almaty scrambling for new work. That 
sense of desperation, underlined by Alibek's defection to the US, has helped pump hundreds of millions of dollars into a Pentagon program to secure not just nuclear materials but chemical and biological ones, in a process by which Washington became, in essence, their highest bidder (Henningsen, 2014).

There have been serious claims that industrialized nations are founding and funding biological weapon laboratories, which they strategically located in developing countries. Africa and specifically West Africa is one of the regions housing some of these institutions. This explains why in 2014 a Liberian, Patrick Sawyer, recognizing he was infected with Ebola in his country flew into Lagos, Nigeria and from all intent and purpose was making efforts to ensure that as many hospital staff as possible contracted the disease. Dr. Stella Ameyo Adadevoh who first diagnosed Mr. Sawyer raised heroic red-flag that saved millions of Nigerians from the onslaught of one of the most deadly viral infections (Ross, 2014, BBC News). Providing answers to the following pertinent questions will at this juncture, accentuate the underlying causes of distrust among the Indigenous peoples: who was Patrick Sawyer working for? How did he contract the dreaded Ebola in Liberia (when the disease was known to exist only in Congo) some 3, 300kilometers away? When Liberia announced the first case of Ebola infection, were the country's airports not screening passengers, why was Mr. Sawyer allowed on international flight to Nigeria the most populous country of Black Africans? Why did Mr. Sawyer choose Nigeria and had to fly over four countries to arrive in Lagos even when he knew he had no relative in the country? Again the $21^{\text {st }}$ Century Wire says:

The United States may be behind the deadly Ebola outbreak in Liberia and Sierra Leone, two West African countries known to host American biological warfare laboratories, a University of Illinois College of Law scholar told RIA Novosti on Wednesday. US government agencies have a long history of carrying out allegedly defensive biological warfare research at labs in Liberia and Sierra Leone... How did Zaire/Ebola get to West Africa from about $3500 \mathrm{~km}$ away from where it was first identified in 1976? (Henningsen, 2014).

The Ebola incident was evocative of similar incidents during the 1918 influenza pandemic that ravaged Africa. Most of the ships conveying the returnee soldiers of WW1 from Europe, who were already infected with influenza virus from Europe, arrived in Nigerian ports via Liberia, Sierra Leone, and Gold Coast (Ghana) and continued spreading the death at very fast rate as they disembarked in other West African countries, and this, to people who neither knew what influenza was nor how to protect themselves against its onslaught. The Ibibio peoples live on the Atlantic coast, along the Niger Delta and their experience was as horrible then as their fear of the current COVID-19 infection. They had just laid down their weapons of warfare and had begun to accept the reality that co- 
lonization represented. They were signing treaties under duress, ceding their land to the British administrators; and suddenly emerged a disease they were unable to explain or find cure for. Many ran into the bushes and swamps to hide, some too late because they had been infected and had to perish in their hideouts. The reaction of the Ibibio peoples to the current COVID-19 pandemic is not altogether different. There was trepidation and panic but with some reservations, because a lot of things have changed since 1918 influenza. Instead of dealing with the British colonial government, Ibibio people have now to receive orders from the (somewhat politically free) Federal, State, and Local Government authorities with respect to COVID-19 pandemic. Yet these tiers of domestic governance are still subservient to and receiving directives from the former colonial masters albeit indirectly through International NGOs. Again, the apprehension invoked by the reportage on mainstream, social and popular media was part of the change. Telegraphs and interpersonal transit communication were the major sources of information during the post-WW1 influenza pandemic, so that diseases spread faster than information on them could reach victims. Today information circulates faster on electronic and social media and people are better equipped to take necessary and precautionary measures to avoid being exposed to infection. Just as the Indigenous Ibibio people were able to locate albeit intuitively, the source of influenza infections in the activities of British and European administrators and business personnel, the events in news reportage of the $21^{\text {st }}$ century media also prepared them to assess and keep wary eyes on foreigners who may likely be infected with the virus. The social distancing and lockdowns imposed by the government was observed so strictly that economic activities were almost grounded in Ibibioland. In fact speculations trailed the social media that COVID outbreak was actually a preplanned and developed neocolonial strategy to depopulate Africa. One of the most disturbing news items was published by the renowned Canadian Broadcasting Corporation (CBC) on $14^{\text {th }}$ June 2020 alleging that deadly viruses were actually sent to Wuhan laboratory in China by scientists, months before the outbreak of the COVID-19 pandemic. As expected, the reaction this news event engendered to the educated Ibibio in Diaspora was apprehension, which they also transferred to relations in Africa. COVID-19 infection did not reach Nigeria early, and when it did, the Ibibio people already were largely prepared to protect themselves against the foreign plague. Karen Pauls of CBC states in a report:

Newly-released access-to-information documents reveal details about a shipment of deadly pathogens last year from Canada's National Microbiology Lab to China-confirming for the first time who sent them, what exactly was shipped, and where it went. CBC News had already reported about the shipment of Ebola and Henipah viruses but there's now confirmation one of the scientists escorted from the lab in Winnipeg amid an RCMP investigation last July was responsible for exporting the pathogens to the Wuhan Institute of Virology four months earlier. Dr. Xiangguo Qiu, her 
husband Keding Cheng and her students from China were removed from Canada's only level-4 lab over what's described as a possible "policy breach". The Public Health Agency of Canada had asked the RCMP to get involved several months earlier (Pauls, 2019).

Unlike the post-WW1 influenza that left ominous marks of demographic decimation on its paths, with heaviest toll on younger people who constituted the work force; COVID-19 has not done much damage to the population of the Indigenous Ibibio peoples. It however unleashed some levels of economic difficulties as many farmers could neither attend to their farms nor traders attend their shops to sell anything due to the lockdown. One other speculation that affected Ibibio peoples' response to COVID-19 emergency healthcare intervention efforts was information from mainstream media stating that COVID-19 outbreak (unlike the post-WWlinfluenza of which the origin was uncertain) originated from Wuhan, China. No sooner this information was published than further reports emerged about many Chinese medical practitioners arriving in Nigeria with huge personal protective equipment, PPE for the people. It was paradoxical to say the least, that China, with a little knowledge of tropical medicine, and nil when it comes to ecologically informed health problems of African peoples; could leave their own citizens who were falling and dying in the streets to attend to Africans that, at this point had no reported cases of COVID-19. It was very difficult for the people to process this information especially when news of arrival of Chinese doctors was flowing through local and international media. The Indigenous people of Ibibio began seeing their government as irresponsible, asking the government why they allowed Nigerian doctors to continue their industrial action but imported Chinese doctors into the country at such a critical moment. They were also suspicious of using the PPE materials brought in from China as many Diaspora Ibibio peoples already speculated that the materials might be contaminated:

Before President Donald Trump started calling the COVID-19 virus the "Chinese Virus", many Nigerians already ascribed "Chinese" characteristics to the COVID-19 virus, thanks to a plethora of conspiracy theories, and videos of Asians (some Chinese) eating bats, and other exotic animals that they've seen on social media... in a statement signed by the NMA President, Dr. Francis A. Faduyile, the association urged the federal government to rescind the decision to bring in Chinese medical experts in the interest of the country (Eguegu, 2020).

\section{Method of Data Collection and Analysis}

We engage sequential text interpretation of historical and current health documents, professional publications and media reportage on the post WW1 influenza and the ongoing COVID-19 pandemics in order to fully explore the tensions and issues arising from the responses of Indigenous Ibibio peoples to the 
pandemics. By sourcing and reviewing relevant historical and analytical literature on the 1918-1921 Influenza and COVID-19 pandemics, we combined works from contemporary social sciences and library catalogs with comprehensive bibliographic search, locating items cited in works identified, and then we followed up relevant items cited in those works. Sequencing refers to the identification of the components of a story - the beginning, middle, and end-and also to the ability to reiterate the events within a given context and texts (emphasis, mine) in the order in which they occurred. The ability to sequence events in a text is a key comprehension strategy, especially for narrative texts. Sequencing is one of many skills that contribute to readers' ability to comprehend what they read. Sequencing refers to the identification of the components of a story-the commencement, central, and conclusion-and also to the ability to retell the events within a given text in the order in which they occurred (emphasis, mine). The ability to sequence events in a text is a key comprehension strategy, especially for narrative texts. Sequencing is also an important component of problem-solving across subjects. The importance of sequential text interpretation lies on its boost of comprehension, especially for narrative texts. It provides readers varying abilities to organize information and ideas efficiently and is also an important component of problem-solving across the narratives and contexts (Reading Rockets, 2021). We also paid special attention to media reports and historical records on how influenza and COVID-19 affected Indigenous peoples around the world with specific focus on Nigeria, and the responses of Indigenous Ibibio people to efforts on vaccination by their domestic government and international NGOs. Drawing on materials identified in our analysis, we engaged the lenses of the peoples' traditional ecological knowledge-base to established a pattern and deduce reasons for the responses of the Indigenous Ibibio people to the two pandemics with regards to the efforts of transnational NGOs and the government to contain the spread of the virus.

\subsection{The Ibibio}

The name Ibibio as used here refers to the African Indigenous peoples who speak Ibibio, who claim a common ancestry, and mostly inhabit the geo-location referred today as the Akwa Ibom State in the Niger Delta area of Nigeria. It is located in area South-Eastern corner of Nigeria roughly between latitudes $4^{\circ} 25^{\prime \prime} \mathrm{N}$ and $5^{\circ} 30^{\prime \prime} \mathrm{N}$ and longitudes $7^{\circ} 30^{\prime \prime} \mathrm{E}$ and $8^{\circ} 30^{\prime \prime} \mathrm{E}$. Ibibio peoples share borders with the Ijaw or Rivers State in the South-West; the Igbo of Abia State to the West and North-West, to the South by the Gulf of Guinea; with the Ekoi as their North and North-Eastern neighbors. The Ibibio occupy the Atlantic Ocean coastline which stretches from Akpayafe river at the Nigeria-Cameroon border in the East to the Andoni river in the West, a distance of more than 130 kilometers; it extends for more than 110 kilometers Northwards to ItuMbonUso which lies South-East of Bende in the Imo state (Abaraonye, 1998). The Ibibio inhabit a flat region with no point reaching $300 \mathrm{ft}$ above sea level. 


\subsection{Discussion: Decolonizing the Pandemics, 1918-21 Influenza and COVID-19}

Despite the hegemonic pressure under which the Indigenous Ibibio people were compelled by the British colonial administration to adopt the language and communication systems of the imposed leadership, the Native peoples have been propagating their own media with news and strategic information relevant to their environment. The aim remains to disrupt existing stereotypes and misrepresentations deployed by the neocolonial media. Contemporary perpetuators of hegemonic socio-political and cultural domination on Indigenous peoples engage the tool of media reinforcement to achieve their goal of complete cultural encapsulation. Continuity of the colonizers' policies and practices in the "postindependent" countries remains the greatest asset of the colonizers' control that persist in securing the bondage of the formerly colonized peoples. The neocolonial processes as they are referred to, surgically remove the Indigenous peoples from their cultural heritages and cultural environments through infliction of traumatic wounds on the psyches of the colonized. WaThiong'O (1986) insists that the most critical area of the colonizers' dominance is the mental universe of the colonized. This notion was corroborated by Sefa Dei and Kempf (2006) that:

The colonizer did not only seize land, but also minds. If colonialism's influence had been merely the control of land that would have required only one form of resistance, but when information is also colonized, it is essential that the resistance must interrogate issues related to education, information and intellectual transformations (p. ix).

We will further draw from Franz Fanon in order to marry colonial experiences with the psychiatry of racism, and the psychology of oppression and control of the mind as weapons of oppression. The colonized peoples all over the world have stomached and continue to bear the degrading symbolic scars of injuries colonization and neo-colonial practices have meted on them and their environment. Fanonian anti-colonial perspective is crucial to this paper as a way of rethinking the mechanics and operations of colonial and re-colonial relations and the implications for decolonization of the socio-cultural processes of the colonized peoples. Colonial in this context means imposition on other peoples' ecological knowledge-base. It also depicts the "extent of state cultural control of resources and human subjects and other direct and indirect processes of domination; for instance, technological, educational, knowledge, and ideological domination" (Dei, 2011, p. 9). The total cultural deracination of the Indigenous peoples starts with gradual erasure of their traditional language, which is the means for culture transmission and communication. The false impression engendered by the colonizers' application of collective catharsis produces conflicting outcomes for both the colonizers and the colonized. In Memmi (1965)'s opinion: 
Possession of two languages is not merely a matter of having two tools, but actually means participation in two psychical and cultural realms. Here, the two worlds symbolized and conveyed by the two tongues are in conflict; they are those of the colonizer and the colonized. (p. 107)

The tension between the colonizers' media, which engage all its tools to sustain a stranglehold on the necks of Indigenous peoples' cultural heritages, and the struggle by the Indigenous people through agency, resistance, and reconnection with their past in order to free themselves from the colonial hegemonic power is subtly lived out in the communication media. Fanon (1952) insists that "to speak a language is to appropriate its world and culture" (p. 21). As the Indigenous peoples strive to deal with colonial language, the Indigenous peoples' traditional language, their tool of education, expression, and transmission of culture yields to the pressure of foreign language of the colonizers. The Indigenous language slowly dies off, leaving the current neocolonial media and educational systems to operate in the language of the colonizers. Memmi (1965) further argues:

The colonized's mother tongue, that which is sustained by his feelings, emotions and dreams, that in which his tenderness and wonder are expressed, thus that which holds the greatest emotional impact, is precisely the one which is the least valued. It has no stature in the country or in the concert of peoples. If he wants to obtain a job, make a place for himself, exist in the community and the world, he must first bow to the language of his masters. (p. 107)

Resonating with Lebakeng (2010)'s and Sefa Dei (2010)'s works, which posit that Western colonization disrupted and destroyed the Indigenous peoples' epistemological and philosophical basis of knowledge production, our work further argues that the colonizer's denigration of the Indigenous peoples' worldviews, which includes labeling African peoples' contribution to world civilization and knowledge systems as inferior and primitive, is an attempt to justify the subjugation, and exploitations of their resources. The suppression entails loss and eventual death of Indigenous cultures and socio-economic structures WaThiong'o (1986) reasons:

But the biggest weapon wielded and actually daily unleashed by imperialism against that collective defiance is the cultural bomb. The effect of a cultural bomb is to annihilate a people's belief in their names, in their languages, in their environment, in their heritage of struggle, in their unity, in their capacities and ultimately in themselves. (p. 3)

Interestingly, the Indigenous Ibibio people twisted the master's hand, using the master's tool against him. They found expression using the social media to communicate between Diaspora and those in Ibibioland, often facilitating education of native people regarding impending dangers in their ecological system. 
Certainly the Nigerian mainstream media have not divorced itself from the stereotypes that characterized the colonizers' media, which was invented over the centuries to justify the repudiation of Native cultures (Belanger, 2018). The persistence of stereotypes is a bombardment to make the Natives lose their sense of esteem and self-confidence, they would begin to judge themselves through the colonizers' lenses, a tactics Simms (2009) referred to as "masked continuity" (p. $\mathrm{x})$. According to Andrew Simms, "when a continent is reduced to economic botany, agronomy and geology, it comes to be seen through a lens of cold accounting, by eyes disinterested in rich history and cultural diversity" (p. ix). This view is consistent with Baxter (2008)'s work, which maintained that Indigenous peoples are "robbed of their confidence and led to believe that their cultures, traditions, and ways of life are out of date in this modern world" (p. 51).

\subsection{Pre-Contact Ibibio Pharmacology and Medicine: Everything but Viral Pandemics?}

In her extensive work on the history of Nigeria, Isichei (1983) laments, "this poignant story of the loss of innocence has parallels among other Nigerian peoples, such as the Kilba. It has been recorded in Ghana and in many other African contexts" (p. 284). She definitely was referring to the predetermined denudation and erasure of the traditional ecological knowledge-base of the Indigenous peoples of Africa. The TEK encompassed the Indigenous peoples' geological, pharmacological, economic, and socio-cultural systems and practices that enabled them navigate through various disasters over centuries. It is pertinent to accentuate here that the Indigenous Ibibio peoples' pre-contact mastery of science and healthcare was not inferior to those brought along by the colonialists. In fact, the colonizers merely introduced Arabic, Western (and currently, Indo-Chinese) versions of these knowledge-bases into Indigenous environments:

A scientific approach, the study of regularities in natural phenomena so that prediction becomes possible, is clear in, for instance, traditional approaches to agriculture and metallurgy. The complexities of many traditional numerical systems, such as those which are duodecimal are almost untouched field which would richly repay further investigation. But the sphere of traditional science which has received most scholarly attention, and which was probably most important in traditional life, is that of medicine (Isichei, 1983, p. 296).

As we hinted earlier in this work, the attempt to erase and rewrite the contribution of African Indigenous peoples to the development of science and technology is an insidious tool colonialists employ to perpetuate the enslavement of the colonized peoples. The "I came, and saw and conquered" ideology is a hogwash as far as documented evidence supported the fact that the colonizers did not encounter uncivilized peoples on their arrival but benefitted immensely 
from the existing traditional ecological knowledge-base of the African Indigenous peoples before imposing their domination.

Traditional societies accumulated an immense knowledge of herbal medicine, which modern scientists are still involved in studying. Osifekunde gives an interesting list of herbal remedies in use among the Ijebu Yoruba in the early ninetheenth century. Early European visitors sometimes owed their lives to Nigerian herbalists. At Adja in Yorubaland in early 1826, Clapperton, who had been very sick recorded: the caboceer brought me some medicine to take, it was like lime juice and pepper. I was so sick that I could not stand for half an hour after I had taken it; I then got suddenly well, both as to the pain in my side and the severe diarrhea which had troubled me for some days (Clapperton, H. cited in Isichei, 1983, p. 297-298).

It is not just about minor health crisis that the Indigenous peoples of Nigeria were specialized, but in neonatal, neurological and psychodynamic procedures. Robinson, in his Hausaland also implied most certainly that the Indigenous peoples of Nigeria possessed at similar degree of competence as the Western medical practitioners, the cure for some virulent and popular diseases like hydrophobia, poisonous snake bites, mental health and seizures etc. It was in effect, such wealthy collection of ecologically informed pharmacological knowledge and practice that nudged the botanist and medical practitioner, Dalziel to articulate the details of Nigerian Indigenous peoples' herbal practices in his " 553 page book", The Useful Plants of West Africa (Dalziel cited in Isichei, 1983, p. 298). There were also some Indigenous medicine practitioners whose ecological knowledge-base had equipped with immense understanding of the human anatomical and physiological systems that they easily treated bone related injuries. Others specialized in minor and complex surgery procedures. Talbot, in his The Peoples of Southern Nigeria, documented a sophisticated surgical procedure he observed thus:

A man, gored in the abdomen by an elephant, replaced the bowels, which had been partially torn out, inserted a small calabash to keep them in place, then drew the skin overall and sewed it across. The shape of the calabash could be clearly seen, but he quite recovered and pursued his ordinary avocations for years (Isichei, 1983, p. 297).

Isichei's concerns were not just to emphasize that pre-contact Indigenous Nigerians were well advanced in healthcare and science, but that many of these Indigenous pharmacological and medical practices were (and are still being) overlooked and allowed to die off while citizens are swept off by the colonial scientific and medical practices that may not be environmentally relevant.

\section{Post-WW1 Influenza: Introduction of a Strange and Foreign Plague}

Shortly after the annexation of Ibibioland was completed, the British particularly 
wasted no time at putting in place the necessary infrastructures to maximally achieve their resource-exploitation goals in the sub-region. Rail routes and network of roads were constructed and in 1918 these modes of transportation and communication were effectively up and running. Suddenly after the opening of the hinterland, in September 1918, the province's sanitary officer sent out telegram messages warning his subjects of the arrival of influenza, which according to him was contagious. Ohadike (1981) hints that the information also indicated that the disease, which was already decimating communities in Sierra Leone and Gold Cost (present, Ghana) was traced to two ocean liners arriving at the Calabar and Forcados quays.

Two cases were actually reported on board such ocean liners as S.S. Batanga, which was anchored at Calabar on the 28th of September. It was also disclosed that "isolated shore cases began to appear after the $7^{\text {th }}$ of October amongst the Marine and Customs Department and the shipping company's employees clearly pointing to infection by ocean ships". While Lagos, Forcados, Port Harcourt and Calabar were the primary focus of infection for the whole of the Southern Provinces (p. 383).

Outstanding in Ohadike's account were: first, a pointer to the likely source of the pandemic. Second, the demographic details of the infection, such that the virus, which affected most of the population, had more fatality among men than women and that the older folks had more immunity than the youth. Because of the level of decimation of the Indigenous population by this disease, more of its fatal victims were in the economically productive segment of the demography, and since the Indigenous Niger Delta population was largely agrarian, acute food shortage resulted as many survivors escaped into the bush presumably to hide from foreign carriers of the disease. The common theme in the reports on 1918-19 influenza pandemic are: its widespread and speed of infection, the inadequacy of Indigenous healthcare system to deal with the outbreak, and acute shortage of Western medicine to treat victims; peoples' ignorant reaction by physically escaping into the bush and other hideaways even after they were infected; and the Indigenous peoples' avoidance of interactions with Europeans who they believed were the source of the disease (see Ohadike, 1981; Isichei, 1983). These apparently suggest that the disease was totally strange and in essence foreign to the Indigenous people. Ibibio people became suspicious that the Europeans might be the source of the disease because it was unknown to them before now and the disease arrived as the British military was taking over their land.

DrMaclaine, Medical Officer, Okigwe, Nigeria, disclosed in 1919 that, "in some places in the district, the natives accused the white man of the introduction of the disease and in consequence became somewhat truculent'. He further disclosed that" the Africans had good reason to fear the disease as in epidemic form it was unknown to them... While we cannot say that in- 
fluenza was a British disease, there is no doubt that its introduction and spread in Nigeria were due to the activities of the British (Ohadike, 1981, p 385).

It is mystifying to observe that in $21^{\text {st }}$ century, the etiology of COVID-19 pandemic and the apposite healthcare measures to stem its devastation on human population is still as difficult a task as those of the post-WW1 Influenza. Fuelled by social and popular media reportage the lingering disposition among the Indigenous communities all over the world remains that of wary suspicion of settler population. Again Phillips (1984) explicate with South African Indigenous peoples' experience:

Once again, reactions to the acute crisis produced by the flu epidemic highlight underlying feelings and attitudes very sharply. Many rural Blacks did not trust Whites and expected the worst of them. "They could not understand why the white man had suddenly grown so solicitous for their welfare", lamented the Christian Express. It went on: this is a terrible impeachment of our attitude towards the Native races, that they could not believe us capable of helping them even in such a season of calamity unless we had behind it some scheme of bettering ourselves. Do the Europeans deserve such distrust? Is there anything in our past treatment of these people to create such suspicion and fear? We ought thoughtfully to ask ourselves this question (Phillips, 1984, p: 167).

Above incriminating rhetorical questions raised by the Christian Express bring to focus the importunate apprehension Indigenous communities around the world have to contend with any time they are confronted with two-prong fork of a pandemic and the resulting media reportage, especially as they struggle to make sense of them with respect to their traditional ecological knowledge-base. The varying ecological, pharmacological, and cultural systems operating within each of the Indigenous communities in Nigeria are, at present, subsumed in the national health emergency arrangements so that the colonizers' Ways of Knowing and philosophical leaning is taken up, reified, and validated as Nigerian ways of attending to the vast life problems. The federal, state, and local government health authorities use the mainstream media to foreground the Western philosophical model on healthcare and emergency management at the space the Indigenous peoples' traditional ecological knowledge TEK is made to dys (appear) to the sneering gaze of the imperialists.

\subsection{COVID-19 Pandemic, the Media and Ibibio Peoples' Skepticism}

Incidents of medical ethics violations, where Indigenous peoples were subjected to certain trial tests without their consent abound and the Ibibio people witnessed one closer home. In 1996 Pfizer, a pharmaceutical giant conducted a test of meningitis vaccine on 200 children of unsuspecting families in Kano, Nigeria. 
Pfizer did not get proper consent for the trial and eleven children died, and the drug was eventually rejected as cure for meningitis because it was noted to have risks of complication. Also shortly after the initial announcements on COVID-19 epidemic in Europe, a social media speculation turned to a full-blown "reality show" where on a BBC interview Dr. Jean-Paul Mira, head of ICU services at the Cochin Hospital in Paris, and Camille Locht, research director for France's National Institute of Health and Medical Research (Inserm) were overheard arguing for the novel corona virus vaccine to be tested on Africans presumably because of the low level of infrastructures in the continent and the Indigenous peoples' "ignorance". In an aired live conversation on French TV network, LCI, Jean-Paul Mira and Camille Locht were saying:

Should we not do this study in Africa, where there are no face masks, no treatments and no ICUs? A bit like it is done for some studies on AIDS, where with prostitutes, we try things because we know that they are highly exposed and they don't protect themselves... You are right, Loch replied. And we are in the process of thinking about a study in Africa in parallel to carry out the same type of approach with BCG, a placebo (Busari \& Wojazer, 2020).

One infers from these disturbing communication faux pas that HIV, Ebola and other epidemics that have ravaged African Indigenous peoples were introduced either involuntarily as failed test-attempt or deliberately (as speculated among Indigenous folks) for reasons of population control. Although Jean-Paul Mira and Camille Locht later tendered apology for their unprofessional and unrestrained comments; and the World Health Organization Director-General, Tedros Ghebreyesus expressed his disapproval of the comments made by the doctors (and with the understanding that most of the global health concerns are founded and funded by the West), it will be very difficult to erase the suspicion generated in the psyche of Indigenous peoples of Africa by these heinous revelations, and thereafter regain the trust people had on these systems. Additionally, the Indigenous peoples may be conditioned to be wary of quasi-philanthropists like Bill Gates who in a February 2011 video interview with CNN's Sanjay Gupta, and in subsequent YouTube-based lectures and workshops not only vented his frustration about the world's overpopulation (relative to resources, with respect to developing nations), but also clarified that he and his wife, Melinda would be working in their Foundation's vaccination projects to help governments to depopulate by making birth control measures available to women, particularly in developing countries (A Conversation with Bill Gates: Population Growth, YouTube.ca, 2012). We would conclude from these conversations that the Ibibio peoples' reactions to the pandemic interventions were direct functions of the media and interpersonal information they gathered from their environment, and processed based on their traditional ecological knowledge-base. It is crucial at this juncture to also draw attention to Bill Gates' mention of Northern Nigeria in his explanation of places he hoped to assist the governments to reduce popula- 
tion through birth control measures. Highlighting this point would enable the reader to make connection between Gates' culturally insensitive statements about his foundation's mission in Africa on one hand and the African Indigenous peoples' suspicion and resistance to all vaccinations on the other. As a consequence, recently the Nigerian legislature was accused by one of the nation's pro-democracy watch-dogs of accepting bribe from foreign firms to pass a bill on forced vaccination. In a press release statement by the Conference of Nigeria Political Parties (CNPP) the political transparency organization called for thorough investigation of the principal officers of the house of representatives following a secret public hearing conducted by the parliament committee on health services and the barring of journalists from covering the process that would lead to the passage of the contentious infectious disease bill. The press release reads in part:

It is time to save not only our democracy but also our public health institution from the apron strings of Western influence who have vowed to turn Nigerians into guinea pigs for experiment in the name of vaccination against infectious disease... and, because of the strong resistance mounted by majority of citizens against the bill that would make vaccination compulsory for all, we expected the House of Reps to hold the Public Hearing online to accommodate more views but they went ahead to even shut out journalists creating more doubt about their sincerity of purpose, (247ureports, 2020).

We will continue by arguing that public trust is essential in community health promotion, and it is the trust that predisposes citizens to comply with government prescribed health interventions, and more specifically with vaccination programs. Absence of public trust on healthcare system has been a fundamental source of anti-vaccine speculations among Indigenous peoples; therefore the Ibibio peoples of South Eastern Nigeria are not an exception. Many factors could erode peoples' confidence and trust in such projects, including such incidents as the unrestrained vocalization of racist comments against a targeted ethnic group; unabashed and brazen repudiation of a peoples' cultural and philosophical leaning and competencies; and willful usurpation of a peoples' right as in Pfizer's role above. The Ibibio Indigenous people of the Niger Delta, just like those in Northern Nigeria, are wary of the free health aids propagated by Western organizations, even when such projects like vaccination and personal protection equipment, PPE are provided by the government in power.

In northern Nigeria in 2003, the political and religious leaders of Kano, Zamfara, and Kaduna states brought the immunization campaign to a halt by calling on parents not to allow their children to be immunized. These leaders argued that the vaccine could be contaminated with anti-fertility agents (estradiol hormone), HIV, and cancerous agents... In the same article, Datti Ahmed, a Kano-based physician who heads a prominent Muslim group, the Supreme Council for Sharia in Nigeria (SCSN), is quoted as say- 
ing that polio vaccines were "corrupted and tainted by evildoers from America and their Western allies". Ahmed went on to say: we believe that modern-day Hitlers have deliberately adulterated the oral polio vaccines with anti-fertility drugs (Jegede, 2007).

It is obvious therefore that in disaster times, where public trust fails between a marginalized social group and the dominant group, speculations and rumors that jeopardize counter-disaster measures travel faster than the disaster itself. We have, by tracing the sources of Indigenous peoples' suspicion and xenophobic response to vaccination and other foreign interventions, established that the Ibibio Indigenous people (as they did in the post-WW1 Influenza) are not alone in the avoidance of COVID-19 pandemic vaccinations and supplies, and that necessary actions must be taken to reinstate the peoples' confidence and trust as a way of reaching them with future counter-disaster programs.

\subsection{Conclusion: The Way Forward, a Multi-World Health Approach}

We would infer from the preceding conversations that the Ibibio peoples' negative response to the pandemic interventions was a direct function of the culture-insensitive remarks of Western NGOs and their stakeholders, and its culminating negative and denigrating media reportage, which in turns, fanned into flame anti-Western speculations among the Indigenous peoples. The inability of the Ibibio peoples to locate the epistemological and etiological foundation for either of the pandemics within the context of their socio-cultural and ecological framework left them with no doubts they were meddling with foreign disease. The recognition that the world is urgently turning into a densely populated global-village impels us to propose a multi-world approach for understanding and finding solutions to global socio-cultural, ecological, and health problems. The Nigerian mainstream media are owned and funded by the neocolonial strategists who are trained to engage European approaches to health-reportage. The imposed measures are symbols of colonial hegemonic grips on the citizenry whose beliefs, philosophical leaning and aspirations are suppressed. To this end, the Indigenous communities of Nigeria are lumped together as one group of people with the same needs and aspirations as far as the COVID-19 pandemic is concerned. Nevertheless, the multi-world approach this paper advocates for, is in recognition that the various Indigenous communities have their distinct Indigenous cultures, norms, values and mores that must be accounted for while dealing with matters affecting them. The inimitable cultural approach each of the Indigenous communities has lived with over the centuries is their identities within the ecological context. These beliefs and practices, including in matters of health and emergency, should be evaluated and incorporated into the plans and projects the government has for the Native peoples.

\section{Conflicts of Interest}

The authors declare no conflicts of interest regarding the publication of this paper. 


\section{References}

247ureports (2020, June 10). Infectious Disease Bill: CNPP Demands Investigation of Reps Principal Officers. 247ureports.

https://247ureports.com/2020/06/infectious-disease-bill-cnpp-demands-investigatio n-of-reps-principal-officers/

Abaraonye, F. I. (1998). Gender and Politics in Ibibioland, 1900-1980. Doctorial Dissertation, University of Lagos.

Baxter, J. (2008). Dust from Our Eyes: An Unblinkered Look at Africa. Wolsak and Wynn Publishers.

Belanger, Y. (2018). Ways of Knowing: An Introduction to Native Studies in Canada (3rd ed.). University of Lethbridge.

Busari, S., \& Wojazer, B. (2020, April 7). French Doctors' Proposal to Test Covid-19 Treatment in Africa Slammed as 'Colonial Mentality'. CNN.

https://edition.cnn.com/2020/04/07/africa/french-doctors-africa-covid-19-intl/index. $\underline{\mathrm{html}}$

Dei, G. (Ed.) (2011). History as a Tool for Colonialism. In G. Dei (Ed.), Teaching Africa: Towards a Transgressive Pedagogy: A Reader (pp. 1-13). Springer.

Eguegu, O. (2020, April 6). Why Are So Many Nigerian Doctors and Journalists Upset About a Chinese Medical Team Coming to Advise on COVID-19? China Africa Project. https://chinaafricaproject.com/analysis/why-nigerian-doctors-journalists-are-so-ups et-about-a-chinese-medical-team-coming-to-advise-on-covid-19/

Fanon, F. (1952). Black Skin White Masks. Grove Press.

Henningsen, P. (2014, October 18). Did Ebola Really Jump from African Fruit Bats to Humans in 1976, or Has This Deadly Pathogen Emerged from a High-Level Bioweapons Lab? 21st Century Wire.

https://21 stcenturywire.com/2014/10/18/weaponized-the-case-for-ebola-coming-fro $\underline{\text { m-a-bioweapons-lab/ }}$

Isichei, E. (1983). A History of Nigeria. Longman Group Limited.

Jegede, A. S. (2007). What Led to the Nigerian Boycott of the Polio Vaccination Campaign? PLoS Medicine, 4, Article No. e73.

https://doi.org/10.1371/journal.pmed.0040073

https://www.ncbi.nlm.nih.gov/pmc/articles/PMC1831725/

Lebakeng, T. (2010). Discourse on Indigenous Knowledge Systems, Sustainable Socio-Economic Development and the Challenge of the Academy in Africa. CODESRIA Bulletin, Nos. 1 \& 2, 24.

Memmi, A. (1965). The Colonizer and the Colonized. Beacon Press.

Nathaniel, S. (2020). COVID-19: Expect Dead Bodies in the Street of African Countries, Melinda Gates Warns. A Snapshot of Melinda Gates in an Interview with CNN. Channels Television.

https://www.channelstv.com/2020/04/13/covid-19-expect-dead-bodies-in-the-streetof-african-countries-melinda-gates-warns/

Nwalutu, M. O. (2015). Education and Schooling. In M. J. Shujaa, \& K. J. Shujaa (Eds.), The Encyclopedia of African Cultural Heritage in North America. Sage Publications Inc. https://doi.org/10.4135/9781483346373.n128

Ohadike, D. C. (1981). The Influenza Pandemic of 1918-19 and the Spread of Cassava Cultivation on the Lower Niger: A Study in Historical Linkages. Journal of African History, 22, 379-391. https://doi.org/10.1017/S0021853700019587 
Pauls, K. (2019, August 4). Canadian Lab's Shipment of Ebola, Henipah Viruses to China Raises Questions. CBCNews. https://www.cbc.ca/news/canada/manitoba/ebola-henipah-china-1.5232674

Phillips, H. (1984). 'Black October': The Impact of the Spanish Influenza Epidemic of 1918 on South Africa. University of Cape Town. http://hdl.handle.net/11427/7852 https://open.uct.ac.za/handle/11427/7852

Reading Rockets (2021). WETA Public Broadcasting. https://www.readingrockets.org/strategies/story_sequence

Ross, W. (2014, October 20). Ebola Crisis: How Nigeria's Dr Adadevoh Fought the Virus. BBC News. https://www.bbc.com/news/world-africa-29696011

Sefa Dei, G. J. (2010). Teaching Africa: Towards a Transgressive Pedagogy. Springer. https://doi.org/10.1007/978-1-4020-5771-7

Sefa Dei, G., \& Kempf, A. (2006). Anti-Colonialism and Education: The Politics of Resistance. Sense Publishers.

Simms, A. (2009). Ecological Debt: Global Warming \& the Wealth of Nations. Pluto Press.

Smith, L. (1999). Decolonizing Methodologies: Research and Indigenous Peoples. Zed Books Ltd.

WaThiong'o, N. (1986). Decolonizing the Mind: The Politics of Language in African Literature. East African Educational Publishers.

Willinsky, J. (1998). Learning to Divide the World: Education at Empire's End. University of Minnesota Press.

YouTube.ca (2012, August 21). A Conversation with Bill Gates: Population Growth. https://www.youtube.com/watch?v=ozlbeXrb_5A 